\title{
ECONOMIC FEASIBILITY OF CABBAGE PRODUCTION UNDER POLYHOUSE CONDITIONS IN SEMI-ARID TROPICS
}

\author{
P. PURUSHOTHAM ${ }^{1}$, K. SADHANA ${ }^{2}$, K. SRINIVAS KUMAR ${ }^{3} \&$ P. SATHVIKA ${ }^{4}$ \\ ${ }^{1,3}$ Department of Water Technology Centre, College of Agriculture, Rajendranagar, Pjtsau, Telangana, India \\ ${ }^{2}$ College of Horticulture, Vellanikkara, Thrissur, Kau, Kerala, India \\ ${ }^{4}$ Department of Agronomy, Shuats, Allahabad, Uttar Pradesh, India
}

\begin{abstract}
Polyhouse cabbage production in semiarid tropical climate suffers from sustainable yields due to lack of optimized irrigation and fertigation levels. The present study is aimed to investigate the economic feasibility of cabbage production in agro-climatic conditions of Southern Telangana. The experiment was laid out in randomized block design with three levels of irrigation and fertigation, replicated thrice to keep the error degree of freedom in limits. The treatments were PHC + Drip irrigation(0.75 Epan) + $100 \% \mathrm{~N}\left(\mathrm{~T}_{1}\right), \mathrm{PHC}+$ Drip irrigation $\left(0.75\right.$ Epan) $+125 \% \mathrm{~N}\left(\mathrm{~T}_{2}\right)$, $\mathrm{PHC}+$ Drip irrigation(0.1 Epan) $+100 \% \mathrm{~N}\left(\mathrm{~T}_{3}\right), \mathrm{PHC}+$ Drip irrigation(1.0 Epan $)+125 \% \mathrm{~N}\left(\mathrm{~T}_{4}\right), \mathrm{PHC}+\mathrm{Drip}$ irrigation(1.25 Epan) $+100 \% N\left(T_{5}\right), P H C+$ Drip irrigation(1.25 Epan $)+125 \% N\left(T_{6}\right), O F C+$ Drip irrigation $(1.0$ Epan $)+100 \% \mathrm{~N}\left(\mathrm{~T}_{7}\right)$, OFC + Drip irrigation(1.0Epan) $+125 \% \mathrm{~N}\left(\mathrm{~T}_{8}\right)$. Economic analysis of polyhouse production among the treatments indicated that maximum net returns ( $\$ 41,861.80 \mathrm{ha}^{-1}$ ) and $\mathrm{B}$ : C ratio (1.80) were associated with $\mathrm{PHC}+$ Drip irrigation $\left(1.0\right.$ Epan) $+125 \% \mathrm{~N}$, while the least net returns (₹3281.56 ha $\left.{ }^{-1}\right)$ and $\mathrm{B}: \mathrm{C}$ ratio $(1.06)$ were observed with $O F C+$ Drip irrigation $(1.0 \times$ Epan $)+100 \% \mathrm{~N}$. The polyhouse grown cabbage production in $384 \mathrm{~m}^{2}$ area is economically viable with $B$ : C ratio of 1.8 and payback period of 4years and 1 month with present level of irrigation and fertigation.

KEYWORDS: PolyHouse, Cabbage, Benefit Cost Ratio, Semi-Arid Region, PHC-Poly House Condition \& OFC-Open Field Condition
\end{abstract}

Received: Jun 29, 2017; Accepted: Jul 16, 2017; Published: Jul 20, 2017; Paper Id.: IJASRAUG201749

\section{INTRODUCTION}

Since ancient times, mankind has been aware of the fact that, a wise modification of the environment could improve the productivity of crops. Polyhouse technology is an appropriate intervention for crop production, particularly in hostile climatic conditions. It has the potential to give manifold production of quality produce round the year from small land holdings, compared to the open field cultivation. It can address the problem of round the year climatic uncertainties as well as price fluctuations by maximizing the productivity per unit area. Vegetable cultivation under polyhouse facilitates manifold production of quality produce round the year, compared to the open field cultivation by integrating market driven quality parameters with production system profits.

Cabbage (Brassica oleracea, L.) is one of the most common cole crops, which thrives best in cool weather conditions of India (Tiwariet al., 2003). With prevailing semiarid tropical climate, there is a potential scope for polyhouse cultivation, especially for remunerative vegetables and export oriented crops, using drip irrigation with different levels of fertigation. 


\section{MATERIALS AND METHODS}

A field experiment was conducted at Horticultural farm, Rajendranagar, Hyderabad, during Rabi season (OctDec) of 2015-2016, to evaluate performance of cabbage under poly house conditions. The experimental site is located in flat land with a latitude of $17^{\circ} 19^{\prime} \mathrm{N}$, longitude of $78^{\circ} 24^{\prime} \mathrm{E}$ and an altitude of $542.3 \mathrm{~m}$ above mean sea level. The local climate is semiarid tropical with an average annual rainfall of $800 \mathrm{~mm}$, of which about $66 \%$ is received during June to October.

A naturally ventilated polyhouse with Saw tooth shape of size $(24 \mathrm{mx} 16 \mathrm{~m})$ was chosen. The polyhouse was oriented towards East-West to get maximum sunshine for photosynthesis during winter. The polyhouse was covered with an Ultra violet (UV) stabilized film of $200 \mu$ thickness and provided with relatively larger ventilation openings (25\% of the floor area) to eliminate the risk of high temperatures during peak summer (Harmantoet al., 2005). The structural design criterion includes the design for primary and secondary systems. The primary structural system includes roof, truss, rigid frame and arch, whereas the secondary structural system includes columns, end frames and foundation materials.

The experiment was laid out using randomized block design with three replications of plot size 21.6 sq. m, eight irrigation accompanied fertigation levels were set out, of which, six under polyhouse condition and the other two under open field condition. All treatments were arranged randomly with three replications for each treatment as a block. To find out the economic viability for cabbage production in poly house, the cost of cultivation, gross returns, net returns and benefit cost ratio were worked out. Under drip fertigation system, 100 per cent recommended NPK registered the highest benefit cost ration (2.17) in chilli (Tumbare and Bhoie, 2002). The highest benefit cost ratio (7.19) in cabbage was obtained in dripline irrigation method followed by drip method (5.45) and micro-sprinkler method (5.12) (Firake and Pawar, 2004). Zamanet al., (2006) from Bangladesh reported that the benefit cost of summer tomato crop was 2.32 and ratio of benefit to variable cost was 3.37 .

\section{RESULTS AND DISCUSSIONS}

Among different levels of drip irrigation and fertigation in the poly house, total production cost was high with PHC + Drip irrigation $(1.25 x$ Epan $)+125 \% \mathrm{~N}\left(₹ .53,390 \mathrm{ha}^{-1}\right)$ followed by treatment consisting of PHC + Drip irrigation $(1.25 \mathrm{xEpan})+100 \% \mathrm{~N}\left(\right.$ ₹. 53,070 $\left.\mathrm{ha}^{-1}\right)$. Lowest production cost was incurred with the treatment of PHC + Drip irrigation $(0.75 \times$ Epan $)+100 \% \mathrm{~N}\left(₹ .50,838 \mathrm{ha}^{-1}\right)$. (Table 1)

However, the net returns were higher with PHC + Drip irrigation (1.0xEpan) + 125\% N (₹. 41,861.80 ha $\left.{ }^{-1}\right)$, followed by GHC + Drip irrigation (1.0xEpan) + 100\% N (₹. 34,465.75 ha ${ }^{-1}$ ), and the lowest with OFC + Drip irrigation $(1.0 x E p a n)+100 \% \mathrm{~N}$ ( ₹. 36,436 ha $\left.{ }^{-1}\right)$. The highest benefit cost ratio (1.80 ) was obtained with PHC + Drip irrigation $(1.0 x E p a n)+125 \% \mathrm{~N}$, followed by PHC + Drip irrigation (1.0xEpan) + 100\% N (1.66), and the least (0.99) was B:C ratio was obtained with OFC + Drip irrigation $(1.0 x E p a n)+100 \%$ N. Similar findings were also reported by Dunageet al. (2009).

The cost of construction of naturally ventilated polyhouse in 384 sq. $\mathrm{m}$ floor area is presented in Table 2 . It is evident from this table that the total cost of the experimental polyhouse including the cost of micro-irrigation, shade net and insect proof net is $₹ 3,50,000.00$, which can be approximated as $₹ 911.45 \mathrm{~m}^{2}$ of floor area. The annual cost of the structure was $₹ 23,880.00$. The total operational cost for production of Cabbage by considering the cost of land preparation and package of practices are ₹ 40,895.00 with gross return of $₹ 71100.00$. The net profit arrived was ₹ $30,205.00$ with 
benefit-cost ratio of 1.73 and a payback period of 4 years 1 month.

Table 1: Treatment Wise Cost of Cultivation $\left(₹ \mathrm{Ha}^{-1}\right)$, Gross Returns $\left(₹ \mathrm{Ha}^{-1}\right)$, Net $\operatorname{Returns}\left(₹ \mathrm{Ha}^{-1}\right)$ and B: C Ratio of Cabbage as Influenced by Irrigation and N-Fertigation Levels

\begin{tabular}{|c|c|c|c|c|}
\hline Treatments & $\begin{array}{c}\text { Cost of } \\
\text { Cultivation } \\
\left(\& \mathrm{ha}^{-1}\right)\end{array}$ & $\begin{array}{c}\text { Gross } \\
\text { Returns } \\
\left(₹ \text { ha }^{-1}\right)\end{array}$ & $\begin{array}{l}\text { Net returns } \\
\left(₹ \mathbf{h a}^{-1}\right)\end{array}$ & $\begin{array}{l}\text { B : C } \\
\text { Ratio }\end{array}$ \\
\hline T1- PHC+Drip Irrigation (0.75 Epan)+100\% N & 50838 & 73302.47 & 22464.47 & 1.44 \\
\hline T2- PHC+Drip Irrigation (0.75 Epan)+125\% N & 51158 & 74845.68 & 23687.68 & 1.46 \\
\hline T3- PHC+Drip Irrigation(1.0 Epan)+100\% N & 51954 & 86419.75 & 34465.75 & 1.66 \\
\hline T4- PHC+Drip Irrigation (1.0 Epan)+125\% N & 52274 & 94135.8 & 41861.80 & 1.80 \\
\hline T5- PHC+Drip Irrigation (1.25 Epan)+100\% N & 53070 & 66358.02 & 13288.02 & 1.25 \\
\hline T6- PHC+Drip Irrigation (1.25 Epan)+125\% N & 53390 & 66358.02 & 12968.02 & 1.24 \\
\hline T7- OFC +Drip Irrigation (1.0 Epan)+100\% N & 51954 & 51697.53 & -256.47 & 0.99 \\
\hline T8- OFC + Drip Irrigation (1.0 Epan)+125\% N & 52274 & 55555.56 & 3281.56 & 1.06 \\
\hline SEm \pm & --- & 4792.98 & 4581.30 & 0.09 \\
\hline $\mathrm{CD}(\mathrm{P}=0.05)$ & --- & 14538.01 & 14714.90 & 0.28 \\
\hline CV (\%) & --- & 11.68 & 44.29 & 11.91 \\
\hline
\end{tabular}

Table 2: Economics of Cabbage Production under Polyhouse (384 M² Floor Area)

\begin{tabular}{|c|c|c|c|}
\hline Sl. No. & Particulars & \multicolumn{2}{|c|}{ Amount (Rs. per crop) } \\
\hline 1 & Materials & Fixed Cost (Rs.) & $\begin{array}{l}\text { Annual } \\
\text { Cost (Rs.) }\end{array}$ \\
\hline & a. $\quad$ Structural cost of greenhouse(life 20 years) & 178480.00 & 23880.00 \\
\hline & $\begin{array}{l}\text { b. Cost of cladding material including shade net and Insect-proof } \\
\text { nets (life } 3 \text { years) }\end{array}$ & 109000.00 & 45780.00 \\
\hline & c. Cost of drip irrigation system including pump set (life 7 years) & 40528.00 & 8916.00 \\
\hline \multicolumn{2}{|r|}{ Total } & 328008.00 & 78576.00 \\
\hline 2 & \multicolumn{3}{|l|}{ Operational Costs } \\
\hline a. & Cost of land preparation and raised beds & Rs. $7 / \mathrm{m}^{2}$ & 1960.00 \\
\hline b. & Cost of FYM/Vermi compost & $\begin{array}{l}0.6 \text { ton @ Rs. } \\
5000 / \text { ton }\end{array}$ & 3500.00 \\
\hline c. & $\begin{array}{l}\text { Cost ofwater soluble fertilizers applied at } 10 \text { days intervals for } 120 \\
\text { days }(9 \text { times })\end{array}$ & $\begin{array}{l}2.7 \mathrm{~kg} \text { per time total } \\
25 \mathrm{~kg} @ \mathrm{Rs} 5 / \mathrm{kg}\end{array}$ & 125.00 \\
\hline d. & Seedlings $($ Spacing $=60 \mathrm{~cm} \times 45 \mathrm{~cm})$ & $1210 @$ Rs.1/plant & 1210.00 \\
\hline e. & Electrical cost & & 1500.00 \\
\hline f. & Water cost & $\begin{array}{l}\text { 1340mm @ 10/ /ha- } \\
\text { mm }\end{array}$ & 13400.00 \\
\hline g. & Labor cost including weeding, spraying, stalking and picking & $\begin{array}{l}60 \text { man days @ Rs. } \\
\text { 200/day }\end{array}$ & 12000.00 \\
\hline i. & Cost of pesticides & & 2000.00 \\
\hline j. & Cost of drip irrigation system maintenance/repair & & 1200.00 \\
\hline $\mathrm{k}$. & Management/Supervision cost & @ 1000/month & 4000.00 \\
\hline \multicolumn{3}{|c|}{ Total Cost } & 40895.00 \\
\hline 3 & \multicolumn{3}{|l|}{ Returns } \\
\hline $\mathrm{A}$ & Average selling price & Rs 5000/tonne & \\
\hline $\mathrm{B}$ & Quantity of produce $\left(\mathrm{t} / 384 \mathrm{~m}^{2}\right)$ & $14.22 \times$ Rs. 5000 & \\
\hline 4 & Gross returns & & $\begin{array}{c}71100 . \\
00\end{array}$ \\
\hline 5 & Net profit & & 30205 \\
\hline 6 & B-C ratio & & 1.73 \\
\hline 7 & Payback period (1 season) & & 4.1 \\
\hline 8 & Payback period (2seasons kharif, Rabi) & & 2.05 \\
\hline
\end{tabular}




\section{CONCLUSIONS}

From the tables ( 1 and 2$)$, it is evident that the polyhouse cabbage production in 384 sq. $\mathrm{m}$ area is found economically viable as the B: C ratio was (1.8).In addition, the payback period worked out was 4years and 1 month, which is affordable for a small and marginal farmers who were interested in taking of polyhouse cultivation in a small area.

\section{REFERENCES}

1. Dunage, V.S., Balakrishnan, P and Patil, M.G. 2009. Water use efficiency and economics of tomato using drip irrigation under net house conditions. Karnataka Journal of Agricultural Science, 22(1): 133-136.

2. Firake, N.N and Pawar, S.J. 2004. DriplineIrrigation : More Economically Viable for Cabbage. Journal of Maharashtra Agricultural Universities, 29(2): 185-186.

3. Harmanto, Salokhe, V.M., Babel, M.S. and Tantau, H.J. 2005. Water requirement of drip irrigated tomatoes grown in greenhouse inn tropical environment. Agricultural Water Management 71(2005): 225-242.

4. Tiwari, G.N. 2003.Greenhouse Technology for Controlled Environment.Narosa Publishing House, New Delhi: 67-77.

5. Tumbare, A.D. and Bhoite, S.V. 2002. Effect of solid soluble fertilizer applied through fertigation on growth and yield of chilli. Indian Journal of Agricultural Sciences, 72(2): 109-111.

6. Zaman, M.M., Anwarulhuq, A.S.M. and Chowdhury, M.J.A. 2006.Production potentiality of summer tomato in jamalpurregion. International journal of sustainbale crop production, 1(2): 12-15. 